\title{
A Systematic Review of Musculoskeletal Injuries Sustained from Submission Techniques in Judo, Brazilian Jiu-Jitsu and Mixed Martial Arts
}

\author{
Andrew Lewis ${ }^{1 *}$, Shane Price ${ }^{2}$ and Anne-Marie Hutchison ${ }^{3}$ \\ ${ }^{1}$ Physiotherapy Department, Swansea Bay University Health Board, Neath Port Talbot Hospital, UK \\ ${ }^{2}$ Ware-house Gym, Unit 42-43, Cwmdu Industrial Estate, Swansea, SA5 8JF, UK \\ ${ }^{3}$ Physiotherapy and Orthopaedic Department, Swansea Bay University Health Board, Neath Port Talbot Hospital, UK
}

Submission: October 19, 2020; Published: April 07, 2021

*Corresponding author: Andrew Lewis, Physiotherapy Department, Swansea Bay University Health Board, Neath Port Talbot Hospital, UK

Abstract

Objective: To determine the risk of musculoskeletal injury from "submission" type finishing techniques in grappling sports (Mixed Martial Arts (MMA), Brazilian Jiu-Jitsu (BJJ) and Judo) in both training and competition settings.

Design: Systematic review without meta-analysis

Materials and methods: A search of published literature databases was undertaken (from their start to November 2020). Two reviewers independently assessed the studies for eligibility using a strict inclusion and exclusion criteria. All eligible articles were assessed against the Clinical Appraisal Skills Programme (CASP). Data on cohort characteristics, number of musculoskeletal injuries, anatomical area injured, type of submission techniques causing the injury and whether the injury was sustained in training or competition were extracted. A narrative research synthesis method was adopted since there were insufficient data to conduct a meta-analysis.

Results: 787 studies were identified. Eleven publications met the review inclusion criteria (MMA n=5, BJJ n=4, Judo $n=2$ ). Methodological quality was generally poor with eight studies at a high or extreme risk of bias. No central injury surveillance database was identified for any of the sports investigated. Seven different anatomical areas were identified as sustaining injury with elbows the most common. A low risk of submission injury exists in competition equivalent to 20.8 injuries per 1000 matches. A higher risk was reported in training with $15.2 \%$ experiencing an injury in a six-month period. Time-loss following injury was reported in only one of 320 injuries.

Conclusion: There are currently no injury surveillance program in submission grappling sports to record injuries that occur during training and competition. Therefore, it is not possible to accurately investigate the prevalence of such injuries from submission techniques in MMA, BJJ or Judo. Accurate databases which record type and severity of injury are required to determine if submission techniques are harmful in both the short and long term. Databases should also record time-loss following injury and volume of injury free sport to enable accurate calculation of risk versus athletic exposure.

Keywords: Submission techniques; Joint lock; Muscular force; Injury patterns

\section{Introduction}

Submission wrestling, also known as submission grappling, is a form of competition and a general term for martial arts and combat sports that focus on clinch and ground fighting with the aim of obtaining capitulation using "submission" techniques. Common examples of such sports include Judo, Brazilian Jiu-Jitsu (BJJ) and Mixed Martial Arts (MMA). They are high contact, aggressive and physically demanding activities, where the contest ends when a competitor concedes defeat by "tapping out", i.e., visibly tapping the floor or the opponent with the hand or saying the word "tap" to signal to the opponent and referee of the submission. These sports are gaining increasing popularity. MMA has been described as the fastest growing sport in the world with an estimated 450 million followers (https://immaf.org/about/) and is now more popular than boxing in males aged 18-34 [1,2]. This increase in popularity is reflected in the potential financial gains which can be made at a professional level, where MMA athletes can earn more than $\$ 10 \mathrm{~m}$ during their career. 


\section{Orthopedics and Rheumatology Open Access Journal (OROAJ)}

Submission techniques are designed to threaten joint injury or unconsciousness in an opponent. A joint lock takes a particular joint of the opponent to its physiological end range then applies additional force to achieve a submission prior to severe injury or intolerable pain. Competitors often attempt to escape such submissions as they are being applied but this is dependent on precise timing often combined with considerable muscular force from both competitors, at the joint end range (see appendix 6 for YouTube examples). Submission techniques and escapes are by their nature potentially harmful and submitting to them is an instant loss. With professional rankings, Olympic medals and significant financial rewards at stake there can be a strong incentive to resist submitting which may further increase the risk of danger and harm.

Recently there has been growing attention on reporting significant long-term injuries and opportunities for prevention in contact sports. Implementing robust injury surveillance programs has been vital to ensure optimal athlete safety in rugby and boxing $[3,4]$. Such data led to coach education programs in rugby reducing moderate to serious injuries by $15 \%$ [3]. Conversely large-scale surveillance in amateur boxing showed no association to serious health concerns defining it as a safe sport and not requiring any changes [4].

A review of the databases PUBMED, MEDLINE, EMBASE and Science Direct (from their start until November 2020) on injury patterns in grappling sports from any mechanism found several studies [5-7]. However, no systematic review has been performed looking specifically at submission injuries sustained in these sports. Different rules across such sports make comparison of risk and injury rates difficult. For example, a common cause of injuries in MMA are facial injuries from punches and kicks to the head [8] yet these techniques are not permitted in either Judo or Brazilian Jiu-jitsu (BJJ). Whilst the main submission-based sports of Judo, $\mathrm{BJJ}$ and MMA have rules to minimize the risk of submission injury, it is unclear if they are effective or appropriate. Given a recent International Olympic Committee consensus statement on injury surveillance [9] the increasing popularity of grappling sports and MMA, with the potential for athlete harm, an investigation into the literature on submission injuries in these sports is required.

The aim of this review was to determine the injuries that may be occurring from joint submission techniques, including the common anatomical joints and structures at risk, if any specific submission technique had a higher prevalence of injury, the severity of such injuries including time-loss and the quality of the available literature.

\section{Materials and Method}

\section{Data source}

The electronic databases PUBMED, MEDLINE, EMBASE and Science Direct were searched in November 2020 from the start of the databases to present. Keywords searched and search strategy are presented in Table 1 with inclusions and exclusions in Table 2.

Table 1: Keywords used with "\$" indicating a truncated search term.

\begin{tabular}{|c|c|}
\hline 1 & Brazilian Jiu-jitsu OR BJJ OR Mixed Martial Arts OR MMA OR Judo OR submission grappling \\
\hline 2 & Injur\$ \\
\hline 3 & Human \\
\hline & 1 AND 2 AND 3 \\
\hline
\end{tabular}

Table 2: Eligibility criteria.

\begin{tabular}{|c|c|}
\hline Inclusion & Exclusion \\
\hline $\begin{array}{c}\text { Article specifically states the injury was caused through applying or escaping submis- } \\
\text { sion technique }\end{array}$ & Injury not musculoskeletal (MSK) in nature \\
\hline English language & Injuries that could not be linked to a submission \\
\hline Involvement in competitive submission-based sports e.g. Judo, BJJ, MMA & \\
\hline Injury occurred in competition or training & \\
\hline
\end{tabular}

\section{Eligibility Criteria}

All observational studies (case control, cross-sectional and cohort studies) which had investigated grappling submission injuries and were in the English language where included. Articles including technical notes, letters and personal opinions were excluded.

\section{Methods of Review}

Studies were independently assessed for inclusion by two reviewers (AMH and $\mathrm{AL}$ ). The reviewers evaluated all identified titles and abstracts after duplications removed, independently against the inclusion criteria. The remaining articles were assessed based on their full texts, if additional studies were identified from the reference lists they were also requested and assessed leading to the sample of eligible articles. PRISMA guidelines were followed throughout the review [10].

\section{Data Extraction}

Data extraction for each eligible paper was performed independently by two reviewers (AMH and AL) using a prepared 


\section{Orthopedics and Rheumatology Open Access Journal (OROAJ)}

data collection sheet. Data extraction included: grappling sport, population characteristics (sample size, age, gender), duration of data collection, number of MSK injuries, injury rate per 1000 athletic exposures, joint affected, specific anatomical structure injured, type of submission techniques used and whether the injury occurred in competition or training.

\section{Critical Appraisal}

Despite a high volume and variation of critical appraisal tools for observational studies, no single gold standard tool has been identified that critiques epidemiological studies [11]. The Clinical Appraisal Skills Programme (CASP) developed in 1993 offers individual tools for different study designs therefore enhancing specificity [12]. Users are guided through 12 questions in three sections supporting the critical analysis of results validity, results interpretation and the applicability of outcomes. Unlike other tools such as the Physiotherapy Evidence Database (PEDro) [13], no numerical / hierarchal score is given by CASP as not all questions carry equal importance. CASP is free to access, easy to use and assesses risk of bias in domains as recommended by the Cochrane Collaboration with adherence to CASP found to enhance conclusions $[12,14]$. The CASP Cohort tool was therefore selected to enhance the validity of this review's conclusions.

As CASP assesses bias in three broad categories of results validity, results interpretation and outcome applicability a scoring system was developed by author consensus to enable comparison between studies with clearer objectivity of the risk of bias. Each study was classified as having an overall low, medium, high or extreme risk of bias with a low risk optimal.

Results

\section{Search strategy}

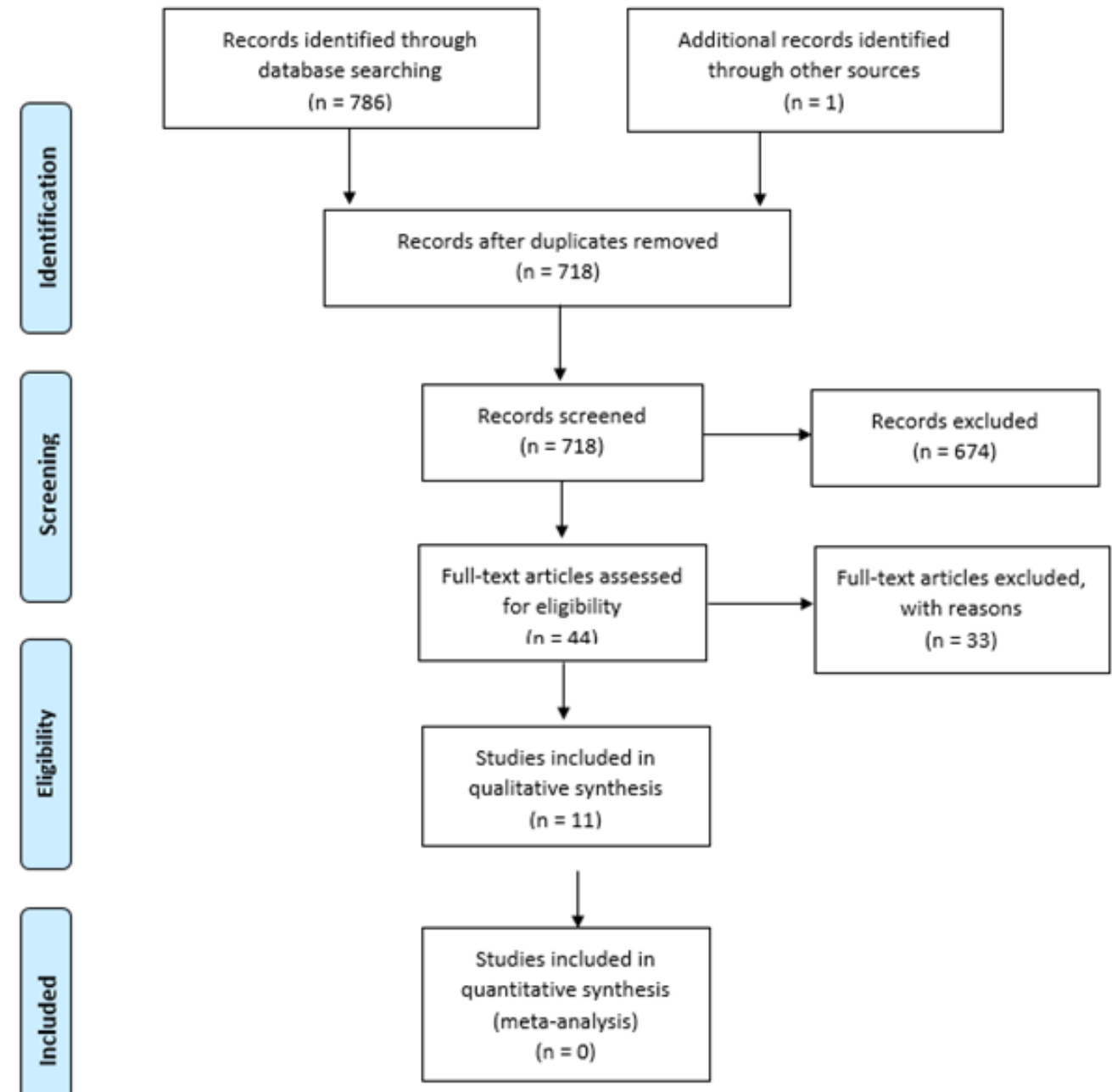

Figure 1: PRISMA flow chart showing search results. 
A total of 787 articles were identified with 69 duplicates leading to 718 unique titles. Their titles and abstracts were reviewed by two authors (AMH and AL) against the eligibility criteria specified in Table 2 leaving 44 requiring assessment of the full text. 33 studies were excluded based on their full text. The most common reasons were the cause of injury not detailed $(n=16)$, injuries were detailed but not from a submission e.g. a throw $(n=8)$, the studies were systematic reviews of papers already identified by this search $(n=4)$. Other reasons included two studies not published in English, one paper was unobtainable, one article collected the relevant data however did not publish the full data set. The lead author was contacted by email to request that data but did not respond. The final excluded paper detailed one submission injury but did not report if it was during Judo or BJJ. That injury could not be assigned to either sport or as there was a low risk of that single injury affecting the outcomes of the review it too was excluded. Eleven articles were included in the final analysis (PRISMA flow chart Figure1).

\section{Data Extraction}

Data extraction for each eligible paper was performed independently by two reviewers (AMH and AL) using a prepared data collection sheet, see Table 3.

Table 3: Data extraction.

\begin{tabular}{|c|c|}
\hline Presence of bias using CASP & Level of risk of bias \\
\hline Obvious bias in all 3 categories & Extreme \\
\hline Obvious bias in 2 categories & High \\
\hline Obvious bias in 1 category & Medium \\
\hline No obvious bias in any category & Low \\
\hline
\end{tabular}

\begin{tabular}{|c|c|c|c|c|c|c|c|c|c|c|c|c|}
\hline Article & Sport & $\begin{array}{l}\text { In- } \\
\text { clud- } \\
\text { ed } n=\end{array}$ & $\begin{array}{c}\text { Age } \\
\text { range } \\
\text { (mean) }\end{array}$ & $\begin{array}{c}\text { Male: } \\
\text { female }\end{array}$ & $\begin{array}{l}\text { Time } \\
\text { span of } \\
\text { study }\end{array}$ & $\begin{array}{c}\text { MSK } \\
\text { inju- } \\
\text { ries } \\
\text { from } \\
\text { sub- } \\
\text { mis- } \\
\text { sion }\end{array}$ & $\begin{array}{c}/ 1000 \\
\text { AE }\end{array}$ & Joint injured & $\begin{array}{l}\text { Specific } \\
\text { anatomy } \\
\text { injured }\end{array}$ & $\begin{array}{l}\text { Named sub- } \\
\text { missions }\end{array}$ & $\begin{array}{c}\text { Injury } \\
\text { sustained in } \\
\text { Competition } \\
\text { or training }\end{array}$ & $\begin{array}{c}\text { Risk of } \\
\text { bias }\end{array}$ \\
\hline $\begin{array}{c}\text { Green } \\
{[18]}\end{array}$ & Judo & 392 & $\begin{array}{l}18-43 \\
(20.9)\end{array}$ & $284: 108$ & 1 comp & 3 & 8 & Elbow 3 & NR & NR & comp & Extreme \\
\hline $\begin{array}{c}\text { James } \\
\text { [19] }\end{array}$ & Judo & 116 & NR & $70: 46$ & 1 comp & 2 & 17 & Elbow 2 & NR & $\begin{array}{c}\text { Armbar } 1 \\
\text { Unknown } 1\end{array}$ & comp & Extreme \\
\hline $\begin{array}{l}\text { das Gra- } \\
\text { cas [15] }\end{array}$ & BJJ & 193 & $\begin{array}{l}12-38 \\
(\mathrm{NR})\end{array}$ & 158:35 & $\begin{array}{l}\text { NR con- } \\
\text { venience } \\
\text { sample }\end{array}$ & 25 & UTA & $\begin{array}{c}\text { Elbow } 13 \\
\text { Shoulder } 9 \\
\text { Hand / wrist } 3\end{array}$ & NR & NR & $\begin{array}{l}\text { Training and } \\
\text { competition } \\
\text { but propor- } \\
\text { tion NR }\end{array}$ & Low \\
\hline $\begin{array}{c}\text { Moriarty } \\
{[16]}\end{array}$ & BJJ & 1287 & $\begin{array}{c}\text { NR } \\
(29.5)\end{array}$ & $1087: 200$ & 6 months & 115 & UTA & NR & NR & NR & $\begin{array}{l}\text { Training and } \\
\text { competition } \\
\text { but } \\
\text { proportion } \\
\text { NR }\end{array}$ & Low \\
\hline $\begin{array}{l}\text { Scoggin } \\
{[20]}\end{array}$ & BJJ & 5022 & NR & NR & 6 years & 36 & 7 & $\begin{array}{c}\text { Elbow } 11 \text { Ankle } \\
1 \text { Shoulder } 1 \\
\text { Neck } 1\end{array}$ & $\begin{array}{c}\text { Elbow: RCL } \\
\text { n=1 UCL n=5, } \\
\text { RCL \& UCL } \\
\text { n=1, distal } \\
\text { bicep strain } \\
\text { n=1, olecra- } \\
\text { non tender- } \\
\text { ness } 3 \text { Ankle: } \\
\text { ATFL sprain } \\
\text { n=1 Shoulder: } \\
\text { ACJ sprain } \\
\text { n=1 Cervical } \\
\text { Spine: strain } \\
\text { n=1 }\end{array}$ & $\begin{array}{c}\text { Armbar } 5 \\
\text { Kimura } 2 \\
\text { Triangle } 1 \\
\text { Footlock } 1\end{array}$ & comp & High \\
\hline
\end{tabular}




\begin{tabular}{|c|c|c|c|c|c|c|c|c|c|c|c|c|}
\hline $\begin{array}{l}\text { de Almei- } \\
\text { da [17] }\end{array}$ & BJJ & 5 & $\begin{array}{l}18-40 \\
(28.8)\end{array}$ & $5: 0$ & 8 months & 5 & $\begin{array}{c}\text { UTA } \\
\text { - case } \\
\text { series }\end{array}$ & Elbow 5 & $\begin{array}{l}\text { Complete UCL } \\
\text { rupture } n=5 \text {, } \\
\text { Micro-frac- } \\
\text { ture / contu- } \\
\text { sion } n=3\end{array}$ & Armbar 5 & comp & Medium \\
\hline $\begin{array}{c}\text { Baker } \\
{[21]}\end{array}$ & MMA & 1 case & 32 & All male & NR & 1 & $\begin{array}{c}\text { UTA } \\
\text { - case } \\
\text { study }\end{array}$ & Knee 1 & $\begin{array}{l}\text { ACL grade } 3 \text {, } \\
\text { MCL grade } 2\end{array}$ & Heel hook & NR & Extreme \\
\hline Buse [22] & MMA & 1284 & $\begin{array}{l}19-51 \\
(29.2)\end{array}$ & All male & 10 years & 94 & 73 & $\begin{array}{c}\text { Elbow } 60 \text { Ankle } \\
13 \text { Shoulder } 11 \\
\text { Knee } 6 \\
\text { Neck } 4\end{array}$ & NR & NR & comp & High \\
\hline Fares [5] & MMA & 570 & NR & $498: 72$ & 2 years & 11 & 19 & NR & NR & NR & Comp & High \\
\hline Ngai [2] & MMA & 1270 & NR & NR & 5 years & 29 & 23 & $\begin{array}{l}\text { UL } 15 \\
\text { LL } 13 \\
\text { LSp } 1\end{array}$ & NR & NR & comp & High \\
\hline $\begin{array}{c}\text { Scoggin } \\
\text { [23] }\end{array}$ & MMA & 232 & $\begin{array}{c}18- \\
40(N R)\end{array}$ & All male & 7 years & 4 & 17 & $\begin{array}{l}\text { Elbow } 3 \\
\text { Ankle } 1\end{array}$ & $\begin{array}{c}\text { Elbow: UCL } \\
\text { n=1, RCL } n=1 \text {, } \\
\text { subluxation } \\
\text { n=1 Ankle: } \\
\text { Achilles con- } \\
\text { tusion } n=1\end{array}$ & $\begin{array}{l}\text { Armbar } 3 \\
\text { Achilles } 1\end{array}$ & Comp & High \\
\hline Summary & $\begin{array}{c}\text { Total } \\
11 \\
\text { Judo } 2 \\
\text { BJJ } 4 \\
\text { MMA } 5\end{array}$ & $\begin{array}{c}\text { Total } \\
10,372 \\
\\
\text { Judo } \\
508 \\
\\
\text { BJJ } \\
6507 \\
\\
\text { MMA } \\
3357\end{array}$ & $\begin{array}{c}\text { Total } \\
12-51 \\
\\
\text { Judo } \\
18-43 \\
\\
\text { BJJ } \\
12-40 \\
\\
\text { MMA } \\
18-51\end{array}$ & $\begin{array}{c}\text { Total } \\
\\
\text { Judo } \\
354: 154 \\
\text { Male } \\
69.7 \% \\
\text { BJJ } \\
\text { 1283:241 } \\
\text { Male } \\
84 \% \\
\\
\\
\text { MMA } \\
\text { 2046:72 } \\
\text { Male } \\
96.7 \%\end{array}$ & $\begin{array}{c}1 \text { day - } 10 \\
\text { years } \\
\\
\text { Judo } \\
1 \text { day } \\
\\
\text { BJJ } \\
6 \\
\text { months-6 } \\
\text { years } \\
\\
\text { MMA } \\
2-10 \\
\text { years }\end{array}$ & $\begin{array}{c}320 \\
\text { Judo } 5 \\
\text { BJJ } 181 \\
\\
\text { MMA } \\
139\end{array}$ & $\begin{array}{c}\text { Mean } \\
\text { comp } \\
\text { injuries } \\
/ 1000 \\
\text { AE } \\
\text { Judo } \\
12.5 \\
\\
\text { BJJ } 7 \\
\\
\text { MMA } \\
33\end{array}$ & $\begin{array}{c}\text { All/Judo/BJJ/ } \\
\text { MMA } \\
\text { Elbow } \\
\text { 97/5/29/63 } \\
\text { Shoulder } \\
\text { 21/0/10/11 } \\
\text { Wrist/hand } \\
\text { 3/0/3/0 } \\
\text { Total UL (Ngai) } \\
\text { 131/5/37/89 } \\
\text { Knee } \\
7 / 0 / 0 / 7 \\
\text { Ankle } \\
\text { 15/0/1/14 } \\
\text { Total LL (Ngai) } \\
\text { 35/0/1/34 } \\
\\
\text { Lumbar } \\
1 / 0 / 0 / 1 \\
\text { Neck } \\
1 / 0 / 1 / 0\end{array}$ & 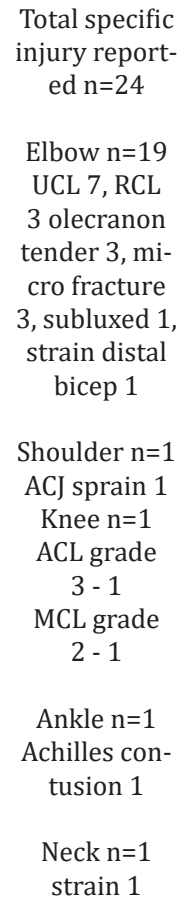 & $\begin{array}{c}\text { All/Judo/BJJ/ } \\
\text { MMA } \\
\text { Upper limb } \\
\text { Armbar } \\
14 / 1 / 9 / 3 \\
\text { Kimura } \\
2 / 0 / 2 / 0 \\
\\
\\
\text { Lower limb } \\
\text { Achilles lock } \\
1 / 0 / 0 / 1 \\
\text { Footlock } \\
1 / 0 / 1 / 0 \\
\text { Heel hook } \\
1 / 0 / 0 / 1 \\
\\
\text { Spine } \\
\text { Triangle } \\
1 / 0 / 1 / 0\end{array}$ & $\begin{array}{c}\text { Comp n=8 } \\
\text { Training n=2 } \\
\text { NR n=1 }\end{array}$ & 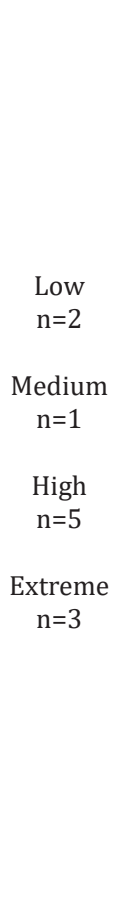 \\
\hline
\end{tabular}

ACJ - acromioclavicular joint, ACL - anterior cruciate ligament, AE - athlete exposure, ATFL - anterior talo-fibular ligament, BJJ - Brazilian Jiu-jitsu, comp - competition, MCL - Medial Collateral ligament (knee), MMA - Mixed martial arts, MSK musculoskeletal, NR - not reported, RCL - radial collateral ligament (elbow), retro - retrospective, UCL- Ulna collateral ligament (elbow), UTA - unable to assess, / 1000 AE - incidence of injury per 1000 athletic exposures.

\section{Data Analysis}

Due to the variation in injury reporting methods, data capture, follow-up periods and different rulesets across BJJ, Judo and MMA a meta-analysis was not appropriate. A descriptive analysis was therefore performed.

\section{Study Design}

Eleven studies including nine observational cohorts, one case series and one case study were included. The duration of data capture varied from a single day of competition ( $\mathrm{n}=2$ both Judo) to a 10-year retrospective analysis (MMA). The method of data 
capture was variable and included attendance to an emergency department $(n=1)$, review by medical support team at the event $(n=6)$, retrospective analysis of televised matches $(n=1)$, retrospective analysis of athletic event records $(n=1)$ or online survey $(\mathrm{n}=2)$.

\section{Sport and competitive distribution}

The distribution by sport of 11 articles were Judo $n=2$ ( $2=$ competition, $0=$ training), BJJ $n=4(2=$ competition, $2=$ training $)$ and MMA n=5 (4= competitions, $1=$ unreported).

\section{Population characteristics}

A total of 10,372 subjects aged 12-51 years were included in this review. Five studies did not report age range, six did not report mean age with only one study including participants aged under 18. Studies included participant numbers from 1 to 5022 with the mean and median of 943 and 392, respectively. Males predominated all studies (male in Judo 69.7\%, BJJ 84\%, MMA $96.7 \%)$.

\section{Injuries}

A total of 185 musculoskeletal injuries were reported in 8891 competitive athlete exposures (matches) representing submission injury rate equivalent to 20.8/1000 matches. The duration of each match was not available and may vary between a few seconds and 15 minutes. Training injuries were only reported in BJJ, with 140 submission injuries in 1480 athletes with one study reporting $13.0 \%$ and a second reporting $15.2 \%$ of competitors had suffered at least one submission injury in a 6 -month period $[15,16]$. Data was not presented on total training hours to enable injury rate to be calculated per 1000 hours. A direct comparison of injury risk between competition and training was therefore not possible.

The elbow was the most frequently injured joint in all sports (elbow $n=97$, shoulder $n=21$, ankle $n=15$, knee $n=7$, wrist/hand $n=3$, lumbar and cervical spine $n=1$ each). Four of the 11 studies reported the anatomical structure injured detailing 29 structures in 24 competitors. The distribution of injuries at the elbow were 11 ulna collateral ligament (UCL), two radial collateral ligament (RCL), one combined UCL/RCL, one distal bicep strain, one subluxation, three olecranon tenderness and three microfractures. One sprain of the acromioclavicular joint and one cervical spine sprain were also reported in the upper body. Lower body injuries included one Achilles contusion, one ATFL sprain and one knee injury involving both the ACL and MCL. The severity of injury was only reported in two studies (6 competitors) included five complete UCL ruptures at the elbow and a complete rupture of the ACL at the knee combined with partial rupture of the MCL.

The highest occurrence of submission injury was in MMA and the most frequent submission leading to injury in all three sports was the "armbar". Time-loss following injury was only reported for one injury out of the 320 included in this review. A female Judo competitor lost 1 week of training following an un-named elbow submission.

\section{Critical Appraisal}

The findings of the critical appraisal (CASP tool) are summarized in Table 3. Only two studies had a low risk of bias $[15,16]$, one study demonstrated a medium risk of bias [17] and 8 were of high or extremely high risk of bias [2,5,18,19,20-23]. The literature highlighted several methodological limitations including under-reporting of exposure, insufficient follow-up, not reporting if the injury was sustained in competition or training and only reporting injury at elite level adult competition. Female competitors, competitors under the age of 18 and amateur / nonelite level competitors are underrepresented in this review.

\section{Discussion}

The aim of this review was to determine the injuries that may be occurring from submission techniques including the common anatomical joints and structures at risk, if any specific submission technique had a higher prevalence of injury, the severity of such injuries including time-loss and the quality of the available literature. To our knowledge this is the first review that has exclusively examined submission injuries affecting the joints in grappling sports. The inclusion criteria of the review were not strict to account for the paucity of literature on this topic. However, despite this just 11 studies met the inclusion criteria and were investigated.

Due to the heterogeneous nature of the studies, it was not possible to conduct a meta-analysis to assess the musculoskeletal injuries sustained from submission techniques. The results of the studies could only be analysed descriptively. No definitive conclusions could therefore be drawn regarding the incidence, anatomical location and type of injury as well as the severity and long-term consequences of injury. The review also revealed that the methodological quality of most studies $(n=8 / 11)$ were poor further affecting the ability to draw any conclusions.

Taking into consideration the above limitations the studies included in this review show a trend that incidence of submission injuries in training is far higher than in competition. Differences in reporting method prevent direct comparison however an injury rate of 20.8 per 1000 competition matches was compared to between $13.0 \%$ and $15.2 \%$ of competitors experience a submission injury in a six-month period whilst training. This may reflect the presence of the referee in competitions. Another explanation is that competitors will typically train for 3 or more hours per week (over 150 hours per year) and compete twice per year amassing less than one hour of total competition with a third choosing never to compete [18]. Therefore, competitors may be exposed to injury 150 times more in training than in competition. This review suggests submission grappling sports are male dominated with just 5 of the 11 studies in this review including females. It is difficult therefore to draw from this study whether there is a relationship between gender and the type of submission 
injury sustained. The most injured joint was the elbow $(n=97)$ followed by the shoulder $(n=21)$, ankle $(n=15)$, knee $(n=7)$, wrist $(n=3)$, lumbar spine $(n=1)$ and cervical spine $(n=1)$. All injuries were from joint locks except one from a strangulation technique (a technique called a "triangle") in a BJJ competition. This accounted for the one cervical spine injury and was diagnosed as a cervical sprain [20].

The most frequently reported joint sustaining injury via submission techniques is the elbow via the "armbar". A sprain / rupture of the ulna collateral ligament (UCL) was the most reported injury $[17,23]$. In a case series of 5 injuries due specifically to the armbar in BJJ, MRI investigation found all had sustained complete UCL rupture with $60 \%$ also sustaining contusion and microfracture to the olecranon or distal humerus [17]. This is not surprising given an investigation of structural strength at the elbow found the UCL to have lower tensile strength than the distal bicep or proximal ulna therefore predicting failure of the UCL initially [24]. Clinicians should always consider assessment of this UCL when competitors present with an elbow injury following an armbar submission.

The "armbar" was the most common submission leading to injury in this review (Figure 2). The practitioner (dressed in white) takes the right elbow of his opponent (dressed in black) to the end of its physiological extension range then applies an additional hyperextension force through active hip and lumbar spine extension until submission or structural failure (YouTube examples provided in appendix 6).

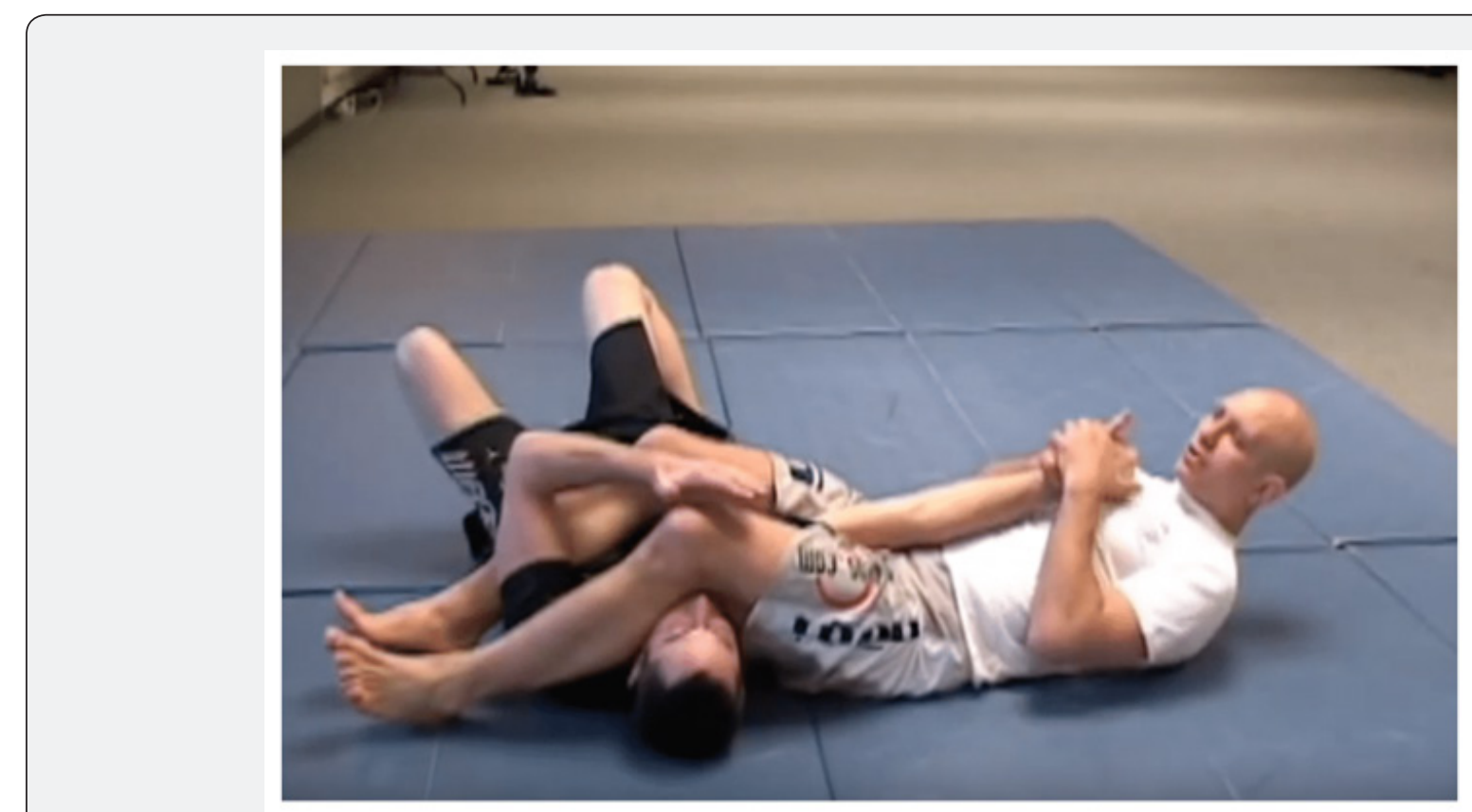

Figure 2: Armbar technique.

Only five studies reported the specific named submissions leading to injury including only six different submission techniques (armbar, kimura, triangle choke, footlock, heel hook, Achilles lock). The total number of possible submissions available to competitors is greater than 30 different techniques (SP). As a consequence, there is currently no complete reliable data on actual injury rate during either competition or training across all submissions.

All eight studies reporting injuries sustained in competition used event only reporting. Competitors may lose a contest through a submission causing a lower-grade joint or ligament injury. As most tournaments are of knock-out formula the athlete may often leave the venue shortly following their defeat. Due to a combination of competition adrenaline and the delay in onset of an inflammatory response the impact of an injury may not be immediately apparent. Event injury reporting may therefore under report such injuries. It was difficult to determine from the review the severity of injury and the potential long-term consequences of injuries. Time-loss was only reported in one injury. A female elite Judo athlete returned to full training in less than 1 week following an armbar submission. The number of injuries leading to athletes choosing to leave the sport has also not been reported in any included study.

Accurate data on injury reporting and time-loss are a significant factor in a competitor's decision-making process on when to submit and when to risk potential injury. A short period of time-loss may encourage competitors to take more risks. A longer recovery, prolonged rehabilitation or surgery would likely dissuade such risk taking. In a survey of BJJ injuries (mechanism not reported) athletes with greater than 4 months of time- 
loss from sport were 5.5 times more likely to consider leaving the sport and 19 times more likely to require surgery with no association to level of experience [7]. A difference may also exist between professional and recreational athletes. For a recreational participant, a significant sports injury may impact on their regular employment and means of income. Such an injury could have a large financial impact, especially if self-employed, possibly contributing to their willingness to risk injury. In contrast to professional athletes where injury with potential quality of life consequences may be risked if a large amount of prize money is at stake.

The low incidence of submission injury in Judo competition was the lowest of the three included sports which may be due to infrequent use of submission attacks in elite competition. The authors (SP and AL) reviewed the outcome of all 539 matches between 481 Judo athletes from 87 countries of the Osaka Judo Grand Slam event in 2019 (breakdown in appendix 6). The only joint submission allowed in Judo are elbow attacks representing $3.2 \%$ of all wins in the female categories and only $0.3 \%$ in males. This infrequent use of such techniques in modern elite Judo may explain the low injury risk in competitions from submissions.

The ADCC (Abu Dhabi Combat Club) Submission Wrestling World Championship is a biennial event representing the highest level of elite multi-discipline grappling. Matches from 2009 and 2019 were reviewed retrospectively by two authors (SP and AL) and illustrated a change in techniques and tactics used at this highest level. In 2009 the armbar was responsible for 11\% of victories, all leg attacks were $10 \%$ of which $3 \%$ were from heel hooks. In 2019 the armbar was less frequent accounting for $5 \%$ of finishes with leg locks rising to $22 \%$ and heel hooks alone $17 \%$ of all submissions (breakdown in appendix 6). The articles reviewed in this study were published at a median date of 2012 (not including the two Judo articles as leg attacks are forbidden). This observed change in tactics may therefore not be reflected in this review and this review has not been able to assess if an increasing use of the heel hook is associated with an increased frequency or severity of injury. A complete UCL rupture at the elbow from an armbar [16] and an anterior cruciate ligament rupture from a heel hook [21] are both highly significant injuries often requiring surgical correction and lengthy delays before returning to sport.

The most striking aspect of the review is there is currently no official reporting / surveillance system for monitoring injuries from submission techniques. Implementing robust injury surveillance programs has been vital to ensure optimal athlete safety in contact sports including rugby and boxing [3,4]. Injury surveillance provided data leading to coach education programs in rugby reducing moderate to serious injuries by $15 \%$ in New Zealand [3]. Conversely large-scale surveillance in amateur boxing showed no association to serious health concerns defining it as a "safe sport" and not requiring rule changes [4]. Implementing such surveillance is feasible to even large-scale events (recording cause of injury and time-loss) representing a basic duty of care. Given the poor quality of literature in this area and the lack of conclusions that are currently able to be drawn around submission injuries, the authors would encourage the international governing bodies of popular submission based grappling sports (International Judo Federation, International Brazilian Jiu-Jitsu Federation, and International Mixed Martial Arts Federation) to invest in injury and illness surveillance programs as recommended by the IOC consensus statement [9]. Such programs will provide large volumes of data for analysis to ensure athlete health is optimised and any changes, if necessary, can be robustly justified. This data will help with the safe evolution of the rules in these sports, if required.

This review has highlighted a potential for significant musculoskeletal injury from submission techniques and the number of injuries in competition appears to be low. Unfortunately, such reporting of injuries sustained were at high to extreme overall risk of bias making conclusions from available literature unreliable. There is insufficient volume and quality of research to suggest a change to the rulesets of included sports and certainly the authors do not recommend such changes. Just as suggestion from governing bodies that removing head shots from boxing would dramatically change the spirit of the sport, so too would be the impact of removing submissions from grappling sports.

\section{Limitations}

No meta-analysis could be performed due to the heterogeneity of rulesets and potential under-reporting of injuries. Studies included were generally at high and extreme risk of overall bias. The injury risk and prevalence in training is under-represented in this review as only two studies (including $14.3 \%$ of the total subjects) investigated injuries in training. Only one injury was reported from a strangulation technique therefore, no conclusions can be drawn around this group of techniques.

\section{Conclusion}

The main findings of this review are that there is currently no surveillance or official databases available to determine the true incidence, type and severity of injury from submission techniques from both competition and training. The studies conducted are mainly of poor methodical quality and therefore it is not currently possible to draw any conclusions around the safety of submission techniques. In conclusion BJJ, Judo and MMA have a low incidence of injury through submission techniques in competition of 7, 12.5 and 33 per 1000 matches, respectively. Training injuries were only reported in BJJ, between $13.0 \%$ and $15.2 \%$ of BJJ athletes reporting at least one injury in a six-month period. Governing bodies should strongly consider implementing injury and illness surveillance programs to further inform this under-researched topic and maintain athlete health. 
Appendix 1: CASP tool assessing risk of bias

\begin{tabular}{|c|c|c|c|c|c|c|c|c|c|}
\hline Question & 1 & 2 & & 3 & 4 & $5 a$ & $5 b$ & $6 a$ & $6 b$ \\
\hline & $\begin{array}{l}\text { Did the } \\
\text { study } \\
\text { address } \\
\text { a clearly } \\
\text { focussed } \\
\text { issue? }\end{array}$ & $\begin{array}{c}\text { Was the } \\
\text { cohort } \\
\text { recruit- } \\
\text { ed in an } \\
\text { acceptable } \\
\text { way? }\end{array}$ & $\begin{array}{l}\text { Is it worth } \\
\text { continuing? }\end{array}$ & $\begin{array}{c}\text { Was the } \\
\text { exposure } \\
\text { accurately } \\
\text { measured } \\
\text { to mini- } \\
\text { mise bias? }\end{array}$ & $\begin{array}{c}\text { Was the } \\
\text { outcome } \\
\text { accurately } \\
\text { measured } \\
\text { to mini- } \\
\text { mise bias? }\end{array}$ & $\begin{array}{l}\text { Have the } \\
\text { authors } \\
\text { identified all } \\
\text { important } \\
\text { confounding } \\
\text { factors? }\end{array}$ & $\begin{array}{l}\text { Have they } \\
\text { taken ac- } \\
\text { count of the } \\
\text { confounding } \\
\text { factors in the } \\
\text { design and/ } \\
\text { or analysis? }\end{array}$ & $\begin{array}{l}\text { Was the fol- } \\
\text { low-up of sub- } \\
\text { jects complete } \\
\text { enough? }\end{array}$ & $\begin{array}{c}\text { Was the } \\
\text { follow-up } \\
\text { of subjects } \\
\text { long } \\
\text { enough? }\end{array}$ \\
\hline
\end{tabular}

Section $\mathbf{A}$ - are the results of the study valid?

\begin{tabular}{|l|c|c|c|}
\hline Question & $\mathbf{7}$ & $\mathbf{8}$ & $\mathbf{9}$ \\
\hline & What are the results of this study & How precise are the results? & Do you believe the results? \\
\hline
\end{tabular}

Section B - what are the results?

\begin{tabular}{|l|c|c|c|}
\hline Question & $\mathbf{1 0}$ & $\mathbf{1 1}$ & $\mathbf{1 2}$ \\
\hline & $\begin{array}{c}\text { Can the results be applied to the local } \\
\text { population? }\end{array}$ & $\begin{array}{c}\text { Do the results of this study fit with the other } \\
\text { available evidence? }\end{array}$ & $\begin{array}{c}\text { What are the implications of this study } \\
\text { for practice? }\end{array}$ \\
\hline
\end{tabular}

Section $\mathbf{C}$ - will the results help locally?

Appendix 2 - CASP tool for Judo

\begin{tabular}{|c|c|c|c|c|c|c|c|c|c|c|c|}
\hline study & Sport & $\mathbf{1}$ & $\mathbf{2}$ & Is it worth continuing? & $\mathbf{3}$ & $\mathbf{4}$ & $\mathbf{5 a}$ & $\mathbf{5 b}$ & $\mathbf{6 a}$ & $\mathbf{6 b}$ & Risk of bias \\
\hline Green 2007 & Judo & yes & yes & yes & Cannot tell & yes & yes & yes & no & no & High \\
\hline James 2003 & Judo & yes & yes & yes & Cannot tell & yes & no & no & yes & no & High \\
\hline
\end{tabular}

Section $\mathbf{A}$ - are the results of the study valid?

\begin{tabular}{|c|c|c|c|c|c|}
\hline Study & Sport & $\mathbf{7}$ & $\mathbf{8}$ & $\mathbf{9}$ \\
\hline $\begin{array}{c}\text { Green } \\
2007\end{array}$ & Judo & $\begin{array}{c}\text { Low incidence of injury from submission in } \\
\text { Judo competition } \\
\text { Elbow most vulnerable }\end{array}$ & $\begin{array}{c}\text { Cannot tell } \\
\text { Absolute numbers recorded } \\
\text { Relies on self-reporting } \\
\text { Did not allow for delay in onset / adrena- } \\
\text { line etc. }\end{array}$ & Cannot tell \\
\hline $\begin{array}{c}\text { James } \\
2003\end{array}$ & Judo & $\begin{array}{c}\text { Low incidence of injury from submission in } \\
\text { Judo competition } \\
\text { Elbow most vulnerable }\end{array}$ & $\begin{array}{c}\text { Cannot tell Absolute numbers recorded } \\
\text { Relies on self-reporting } \\
\text { Did not allow for delay in onset / adrena- } \\
\text { line etc. }\end{array}$ & Cannot tell \\
\hline
\end{tabular}

\section{Section B - what are the results?}

\begin{tabular}{|c|c|c|c|c|c|}
\hline Study & Sport & $\mathbf{1 0}$ & $\mathbf{1 1}$ & $\mathbf{1 2}$ & Risk of Bias \\
\hline Green 2007 & Judo & $\begin{array}{c}\text { Yes but elite athletes and competition only } \\
\text { No data on training }\end{array}$ & no & $\begin{array}{c}\text { Low incidence in judo } \\
\text { Elbow most commonly affected }\end{array}$ & High \\
\hline James 2003 & Judo & $\begin{array}{c}\text { Yes but elite athletes and competition only } \\
\text { No data on training }\end{array}$ & no & $\begin{array}{c}\text { Low incidence in judo } \\
\text { Elbow most commonly affected }\end{array}$ & High \\
\hline
\end{tabular}

Section $\mathbf{C}$ - will the results help locally? 
Appendix 3 - CASP tool for BJJ competition

\begin{tabular}{|c|c|c|c|c|c|c|c|c|c|c|c|}
\hline Study & Sport & $\mathbf{1}$ & $\mathbf{2}$ & $\begin{array}{c}\text { Is it worth } \\
\text { continuing? }\end{array}$ & $\mathbf{3}$ & $\mathbf{4}$ & $\mathbf{5 a}$ & $\mathbf{5 b}$ & $\mathbf{6 a}$ & $\mathbf{6 b}$ & Risk of Bias \\
\hline $\begin{array}{c}\text { Scoggin } \\
2014\end{array}$ & BJJ & yes & yes & yes & Cannot tell & yes & yes & yes & no & no & High \\
\hline $\begin{array}{c}\text { Almei- } \\
\text { da } \\
2017\end{array}$ & BJJ & yes & yes & yes & $\begin{array}{c}\text { No retro- } \\
\text { spective case } \\
\text { series }\end{array}$ & yes & yes & $\begin{array}{c}\text { No elite male } \\
\text { adults only }\end{array}$ & yes & yes & Low \\
\hline
\end{tabular}

Section $\mathrm{A}$ - are the results of the study valid?

\begin{tabular}{|c|c|c|c|c|c|}
\hline Study & Sport & $\mathbf{7}$ & $\mathbf{8}$ & $\mathbf{9}$ & Risk of Bias \\
\hline $\begin{array}{c}\text { Scoggin } \\
2014\end{array}$ & BJJ & $\begin{array}{c}\text { Low risk of submission injury } \\
\text { Upper limb most vulnerable } \\
\text { Armbar predominates }\end{array}$ & $\begin{array}{c}\text { Cannot tell Absolute numbers } \\
\text { recorded } \\
\text { More robust data capturing }\end{array}$ & $\begin{array}{c}\text { Yes, similar to Judo and Almeida } \\
2017\end{array}$ & High \\
\hline $\begin{array}{c}\text { Almeida } \\
2017\end{array}$ & BJJ & $\begin{array}{c}\text { Complete UCL rupture common fol- } \\
\text { lowing an armbar injury }\end{array}$ & $\begin{array}{c}\text { Yes Injury reporting accurate } \\
\text { from MRI and experienced } \\
\text { clinician assessment }\end{array}$ & Yes, similar to Scoggin 2014 & Low \\
\hline
\end{tabular}

\section{Section B - what are the results?}

\begin{tabular}{|c|c|c|c|c|c|}
\hline Study & Sport & $\mathbf{1 0}$ & $\mathbf{1 1}$ & $\mathbf{1 2}$ & Risk of Bias \\
\hline $\begin{array}{c}\text { Scoggin } \\
2014\end{array}$ & BJJ & $\begin{array}{c}\text { Yes Competition only, good age } \\
\text { range }\end{array}$ & n/a & $\begin{array}{c}\text { Upper limb most vulnerable, highest incidence } \\
\text { with armbar }\end{array}$ & Low \\
\hline $\begin{array}{c}\text { Almeida } \\
2017\end{array}$ & BJJ & No Elite adult males only & Yes & $\begin{array}{c}\text { Medial and posterior elbow the focus of assess- } \\
\text { ment and rehabilitation }\end{array}$ & High \\
\hline
\end{tabular}

Section $\mathbf{C}$ - will the results help locally?

Appendix 4 - CASP tool for BJJ training

\begin{tabular}{|c|c|c|c|c|c|c|c|c|c|c|c|}
\hline Study & Sport & 1 & 2 & $\begin{array}{l}\text { Is it worth con- } \\
\text { tinuing? }\end{array}$ & 3 & 4 & $5 a$ & $5 b$ & $6 a$ & $6 b$ & $\begin{array}{c}\text { Risk } \\
\text { of } \\
\text { Bias }\end{array}$ \\
\hline $\begin{array}{l}\text { Das Gracias } \\
2017\end{array}$ & BJJ & yes & yes & yes & yes & yes & yes & yes & yes & yes & Low \\
\hline $\begin{array}{l}\text { Moriarty } \\
2019\end{array}$ & BJJ & yes & yes & yes & yes & $\begin{array}{c}\text { Yes low risk of recall bias } \\
\text { over } 6 \text { months }\end{array}$ & yes & yes & yes & yes & Low \\
\hline
\end{tabular}

Section $\mathbf{A}$ - are the results of the study valid?

\begin{tabular}{|c|c|c|c|c|c|}
\hline Study & Sport & $\mathbf{7}$ & $\mathbf{8}$ & $\mathbf{9}$ & Risk of Bias \\
\hline $\begin{array}{c}\text { Das Gracias } \\
2017\end{array}$ & BJJ & $\begin{array}{c}\text { Higher risk of submission injury in } \\
\text { training than competition UL more } \\
\text { vulnerable }\end{array}$ & $\begin{array}{c}\text { Absolute numbers } \\
\text { recorded Relies on } \\
\text { self-reporting }\end{array}$ & $\begin{array}{c}\text { Higher injury rate propor- } \\
\text { tional to higher partici- } \\
\text { pation }\end{array}$ & $\begin{array}{c}\text { Yes } \\
\text { Moriarty } \\
2019\end{array}$ \\
\hline BJJ & $\begin{array}{c}\text { Higher risk of submission injury in } \\
\text { training than competition lacks detail of } \\
\text { location and specific submissions }\end{array}$ & $\begin{array}{c}\text { Absolute numbers } \\
\text { recorded Relies on } \\
\text { self-reporting }\end{array}$ & $\begin{array}{c}\text { Higher injury rate propor- } \\
\text { tional to higher partici- } \\
\text { pation }\end{array}$ & Low \\
\hline
\end{tabular}

\footnotetext{
Section B - what are the results?
} 


\begin{tabular}{|c|c|c|c|c|c|}
\hline Study & Sport & $\mathbf{1 0}$ & $\mathbf{1 1}$ & $\mathbf{1 2}$ & Risk of Bias \\
\hline Das Gracias 2017 & BJJ & yes & $\begin{array}{c}\text { yes } \\
\text { similar to Moriarty }\end{array}$ & $\begin{array}{c}\text { Increased incidence with training } \\
\text { Focus on upper limb injuries required }\end{array}$ \\
\hline Moriarty 2019 & BJJ & Yes & $\begin{array}{c}\text { Yes } \\
\text { similar to Das } \\
\text { Gracias }\end{array}$ & Lacks detail to target a change in practice \\
\hline
\end{tabular}

Section $\mathbf{C}$ - will the results help locally?

\section{Appendix 5- CASP tool for MMA}

\begin{tabular}{|c|c|c|c|c|c|c|c|c|c|c|c|}
\hline Study & Sport & $\mathbf{1}$ & $\mathbf{2}$ & $\begin{array}{c}\text { Is it worth continu- } \\
\text { ing? }\end{array}$ & $\mathbf{3}$ & $\mathbf{4}$ & $\mathbf{5 a}$ & $\mathbf{5 b}$ & $\mathbf{6 a}$ & $\mathbf{6 b}$ & Risk of Bias \\
\hline Baker 2010 & MMA & no & no & no & n/a & n/a & n/a & n/a & n/a & n/a & High \\
\hline Buse 2005 & MMA & yes & yes & yes & Yes & $\begin{array}{c}\text { No } \\
\text { video } \\
\text { only }\end{array}$ & yes & $\begin{array}{c}\text { Adult males } \\
\text { only }\end{array}$ & no & no & High \\
\hline Fares 2019 & MMA & yes & yes & yes & Yes & yes & yes & yes & no & no & High \\
\hline Ngai 2008 & MMA & yes & yes & yes & yes & Yes & yes & yes & no & no & High \\
\hline $\begin{array}{c}\text { Scoggin } \\
2010\end{array}$ & MMA & yes & yes & yes & Yes & yes & no & no & no & no & High \\
\hline
\end{tabular}

Section $\mathbf{A}$ - are the results of the study valid?

\begin{tabular}{|c|c|c|c|c|c|}
\hline Study & Sport & 7 & 8 & 9 & Risk of Bias \\
\hline Baker 2010 & MMA & $\mathrm{n} / \mathrm{a}$ & $\mathrm{n} / \mathrm{a}$ & $\mathrm{n} / \mathrm{a}$ & High \\
\hline Buse 2005 & MMA & $\begin{array}{l}\text { Moderate incidence } \\
\text { Submission not reported }\end{array}$ & $\begin{array}{l}\text { Reporting of absolute numbers } \\
\text { Not included ring side assessment }\end{array}$ & yes & Low \\
\hline Fares 2019 & MMA & $\begin{array}{l}\text { Low incidence } \\
\text { Not reported submission or location }\end{array}$ & $\begin{array}{l}\text { Likely underestimation of effect } \\
\text { Absolute numbers recorded Small numbers }\end{array}$ & Yes & Low \\
\hline Ngai 2008 & MMA & $\begin{array}{l}\text { Low incidence of submission injury } \\
\text { Upper limb most vulnerable }\end{array}$ & $\begin{array}{l}\text { Absolute numbers recorded } \\
\text { Submissions and affected joints not recorded }\end{array}$ & yes & Low \\
\hline Scoggin 2010 & MMA & $\begin{array}{l}\text { Low incidence of submission injury } \\
\text { Elbow most injured } \\
\text { Armbar most common submission }\end{array}$ & $\begin{array}{l}\text { Absolute numbers recorded } \\
\text { Small numbers }\end{array}$ & Yes & Low \\
\hline
\end{tabular}

Section B - what are the results?

\begin{tabular}{|c|c|c|c|c|c|}
\hline Study & Sport & 10 & 11 & 12 & $\begin{array}{l}\text { Risk of } \\
\text { Bias }\end{array}$ \\
\hline Baker 2010 & MMA & $\mathrm{n} / \mathrm{a}$ & $\mathrm{n} / \mathrm{a}$ & $\mathrm{n} / \mathrm{a}$ & High \\
\hline Buse 2005 & MMA & $\begin{array}{l}\text { no only includes professional adult males } \\
\text { Not reflective of amateur, teens, training } \\
\text { Study completed } 17 \text { years ago so possible ad- } \\
\text { vances in rules / technique / training methods / } \\
\text { engagement / participation etc. }\end{array}$ & $\begin{array}{l}\text { No } 3 \mathrm{x} \text { incidence of other } \\
\text { studies, possible reasons } \\
\text { see question } 10\end{array}$ & $\begin{array}{l}\text { Elbow and ankle most } \\
\text { vulnerable }\end{array}$ & High \\
\hline Fares 2019 & MMA & $\begin{array}{l}\text { No but includes only professional adults } \\
\text { Not reflective of amateur, teens, training injuries }\end{array}$ & yes & Lacks detail to target & High \\
\hline
\end{tabular}




\section{Orthopedics and Rheumatology Open Access Journal (OROAJ)}

\begin{tabular}{|c|c|c|c|c|c|}
\hline Ngai 2008 & MMA & $\begin{array}{l}\text { No but includes only professional adults } \\
\text { Not reflective of amateur, teens, training injuries }\end{array}$ & yes & $\begin{array}{l}\text { Upper limb more } \\
\text { vulnerable than lower } \\
\text { limb }\end{array}$ & High \\
\hline $\begin{array}{l}\text { Scoggin } \\
2010\end{array}$ & MMA & $\begin{array}{l}\text { No only includes professional adults males } \\
\text { Not reflective of amateur, teens, training injuries }\end{array}$ & yes & $\begin{array}{c}\text { Focus attention on } \\
\text { armbar and elbow } \\
\text { injury }\end{array}$ & High \\
\hline
\end{tabular}

Section $\mathbf{C}$ - will the results help locally?

Appendix 6 - Extracted tournament results and YouTube examples

\begin{tabular}{|c|c|c|c|c|c|c|c|}
\hline & Weight classes & competitions & Ground finishes & Strangles & Armbar & Other elbow & Pins \\
\hline Female & 7 & 246 & $\begin{array}{c}65 \\
(26.4 \%)\end{array}$ & $\begin{array}{c}9 \\
(3.7 \%)\end{array}$ & $\begin{array}{c}7 \\
(2.8 \%)\end{array}$ & $\begin{array}{c}1 \\
(0.4 \%)\end{array}$ & $\begin{array}{c}19 \\
(7.7)\end{array}$ \\
\hline Male & 7 & 293 & $\begin{array}{c}38 \\
(13.0 \%)\end{array}$ & $5(1.7 \%)$ & $\begin{array}{c}1 \\
(0.3 \%)\end{array}$ & 0 & $\begin{array}{c}32 \\
(10.9 \%)\end{array}$ \\
\hline total & & 539 & $\begin{array}{c}103 \\
(19.1 \%)\end{array}$ & $\begin{array}{c}14 \\
(2.4 \%)\end{array}$ & $\begin{array}{c}8 \\
(1.5 \%)\end{array}$ & $\begin{array}{c}1 \\
(0.2 \%)\end{array}$ & $\begin{array}{c}80 \\
(14.8 \%)\end{array}$ \\
\hline
\end{tabular}

Table of victories due to ground grappling finishes in Judo Osaka Grand Slam IJF circuit 2019.

\begin{tabular}{|c|c|c|c|c|c|c|}
\hline ADCC year & Matches & Strangle / choke & Heel Hook & Armbar & Other leg attacks & Kimura \\
\hline 2009 & 104 & $\begin{array}{c}23 \\
(22 \%)\end{array}$ & $\begin{array}{c}3 \\
(3 \%)\end{array}$ & $\begin{array}{c}11 \\
(11 \%)\end{array}$ & $\begin{array}{c}2 \\
(2 \%)\end{array}$ \\
\hline 2019 & 41 & 5 & 7 & 2 & 2 \\
$(12 \%)$ & $(17 \%)$ & $(5 \%)$ & $(2.4 \%)$ \\
\hline
\end{tabular}

Table of submission finishes in ADCC tournament in 2009 and 2019.

YouTube examples or armbar and heel hook submissions used in competition

Compilation of armbars in Judo competition:

https://www.youtube.com/watch?v=HOOSxtw7|RI

Armbar defended at $7 \mathrm{~min} 30 \mathrm{sec}$ :

https://www.youtube.com/watch?v=NOfCfsg76eY

Armbar injury at 55sec:

Heel hooks in competition (ADCC):

Heel hooks in MMA:

https://www.youtube.com/watch?v=kMeHW-mYJxU

https://www.youtube.com/watch?v=GwoYcWM66_M

https://www.youtube.com/watch?v=jlZRE9ivcec

\section{References}

1. Ross, DJ, Tudor GJ, Hafner JW, Yahuaca BI, Wang H (2013) Injury patterns of mixed martial arts athletes in the United States. Annals of Emergency Medicine 4(62): S108.

2. Ngai KM, Levy F, Hsu EB (2008) Injury trends in sanctioned mixed martial arts competition: a 5-year review from 2002 to 2007. British journal of sports medicine 42(8): 686-689.

3. Freitag A, Kirkwood G, Pollock AM (2015) Rugby injury surveillance and prevention programmes: are they effective? bmj, 350

4. Bianco M, Loosemore M, Daniele G, Palmieri V, Faina M, et al. (2013) Amateur boxing in the last 59 years. Impact of rules changes on the type of verdicts recorded and implications on boxers' health. British journal of sports medicine 47(7): 452-457.

5. Fares MY, Fares J, Fares Y, Abboud JA (2019) Musculoskeletal and head injuries in the ultimate fighting championship (UFC). The Physician and sports medicine 47(2): 205-211.

6. Frey A, Lambert C, Vesselle B, Rousseau R, Dor F, et al. (2019) Epidemiology of judo-related injuries in 21 seasons of competitions in France: a prospective study of relevant traumatic injuries. Orthopaedic journal of sports medicine 7(5): p.2325967119847470.
7. Petrisor BA, Del Fabbro G, Madden K, Khan M, Joslin J, et al. (2019) Injury in Brazilian jiu-jitsu training. Sports health 11(5): 432-439.

8. Bledsoe GH, Hsu EB, Grabowski JG, Brill JD, Li G (2006) Incidence of injury in professional mixed martial arts competitions. Journal of sports science \& medicine 5(CSSI): 136-142.

9. Bahr R, Clarsen B, Derman W, Dvorak, J, Emery CA, et al. (2020) International Olympic Committee Injury and Illness Epidemiology Consensus Group. International Olympic Committee consensus statement: methods for recording and reporting of epidemiological data on injury and illness in sports 2020 (including the STROBE extension for sports injury and illness surveillance (STROBE-SIIS)). Orthopaedic journal of sports medicine 8(2): p.2325967120902908.

10. Liberati A, Altman DG, Tetzlaff J, Mulrow C, Gøtzsche PC, et al. (2009) The PRISMA statement for reporting systematic reviews and metaanalyses of studies that evaluate health care interventions: explanation and elaboration. Journal of clinical epidemiology 62(10): e1-e34.

11. Katrak P, Bialocerkowski AE, Massy Westropp N, Kumar VS, Grimmer KA (2004) A systematic review of the content of critical appraisal tools. BMC medical research methodology 4(1): 1-11.

12. Singh J (2013) Critical appraisal skills programme. Journal of pharmacology and Pharmacotherapeutics 4(1): 76. 
13. Elkins MR, Moseley AM, Sherrington C, Herbert RD, Maher CG (2013) Growth in the Physiotherapy Evidence Database (PEDro) and use of the PEDro scale 47(4): 188-189.

14. Bradley P, Burls AJ (1999) Critical Appraisal Skills Programme: a project in critical appraisal skills teaching to improve the quality in health care. Journal of Clinical Governance-Leicester 7: 88-91.

15. Das Graças D, Nakamura L, Barbosa FSS, Martinez PF, Reis FA, et al. (2017) Could current factors be associated with retrospective sports injuries in Brazilian jiu-jitsu? A cross-sectional study. BMC sports science, medicine and rehabilitation 9(1): 1-10.

16. Moriarty C, Charnoff J, Felix ER (2019) Injury rate and pattern among Brazilian jiu-jitsu practitioners: A survey study. Physical therapy in sport 39: 107-113.

17. De Almeida TBCD, Dobashi ET, Nishimi AY, Almeida Junior EBD, Pascarelli L, et al. (2017) Analysis of the pattern and mechanism of elbow injuries related to armbar-type armlocks in jiu-jitsu fighters. Acta ortopedica brasileira 25(5): 209-211.

18. Green CM, Petrou MJ, Fogarty Hover ML, Rolf CG (2007) Injuries among judokas during competition. Scandinavian journal of medicine \& science in sports 17(3): 205-210.
19. James G, Pieter W (2003) Injury rates in adult elite judoka. Biology of Sport 20(1): 25-32.

20. Scoggin III JF, Brusovanik G, Izuka BH, Zandee van Rilland E, Geling O, et al. (2014) Assessment of injuries during Brazilian jiu-jitsu competition. Orthopaedic journal of sports medicine 2(2): 2325967114522184.

21. Baker JF, Devitt BM, Moran R (2010) Anterior cruciate ligament rupture secondary to a 'heel hook': a dangerous martial arts technique. Knee surgery, sports traumatology, arthroscopy 18(1): 115-116.

22. Buse George J (2006) No holds barred sport fighting: a 10-year review of mixed martial arts competition. British journal of sports medicine 40(2): 169-172.

23. Scoggin $3^{\text {rd }}$ JF, Brusovanik G, Pi M, Izuka B, Pang P, et al. (2010) Assessment of injuries sustained in mixed martial arts competition. Am J Orthop (Belle Mead NJ) 39(5): 247-251.

24. Lonsdale L, Deamer K, Lieu E (2014) What happens if an arm lock goes too far? Journal of Interdisciplinary Science Topics, 2: 13.

\section{Your next submission with Juniper Publishers} will reach you the below assets

- Quality Editorial service

- Swift Peer Review

- Reprints availability

- E-prints Service

- Manuscript Podcast for convenient understanding

- Global attainment for your research

- Manuscript accessibility in different formats ( Pdf, E-pub, Full Text, Audio)

- Unceasing customer service

Track the below URL for one-step submission https://juniperpublishers.com/online-submission.php 